\title{
Deep convective injection of boundary layer air into the lowermost stratosphere at midlatitudes
}

\author{
H. Fischer ${ }^{1}$, M. de Reus ${ }^{1}$, M. Traub ${ }^{1}$, J. Williams ${ }^{1}$, J. Lelieveld ${ }^{1}$, J. de Gouw ${ }^{2}$, C. Warneke ${ }^{2}$, H. Schlager ${ }^{3}$, A. \\ Minikin $^{3}$, R. Scheele ${ }^{4}$, and P. Siegmund ${ }^{4}$ \\ ${ }^{1}$ Max Planck Institute for Chemistry, Mainz, Germany \\ ${ }^{2}$ CIRES and NOAA Aeronomy Laboratory, Boulder, Colorado, USA \\ ${ }^{3}$ Institute for Atmospheric Physics, DLR, Oberpfaffenhofen, Germany \\ ${ }^{4}$ KNMI, de Bilt, The Netherlands
}

Received: 30 August 2002 - Published in Atmos. Chem. Phys. Discuss.: 11 November 2002

Revised: 11 June 2003 - Accepted: 12 June 2003 - Published: 17 June 2003

\begin{abstract}
On 22 August 2001 a measurement flight was performed with the German research aircraft FALCON from Sardinia to Crete as part of the Mediterranean Oxidant Study (MINOS). Cruising at $8.2 \mathrm{~km}$, the aircraft was forced to climb to $11.2 \mathrm{~km}$ over the southern tip of Italy to stay clear of the anvil of a large cumulonimbus tower. During ascent into the lowermost stratosphere in-situ measurements onboard the FALCON indicated several sharp increases in the concentrations of tropospheric trace gases, e.g. CO, acetone, methanol, benzene and acetonitrile, above the anvil. During one particular event deep in the stratosphere, at $\mathrm{O}_{3}$ concentrations exceeding $200 \mathrm{ppv}, \mathrm{CO}$ increased from about 60 to $90 \mathrm{ppv}$, while the concentration of acetone and methanol increased by more than a factor of 2 ( 0.7 to $1.8 \mathrm{ppv}$ for acetone; 0.4 to $1.4 \mathrm{ppv}$ for methanol). Enhancements for the short lived species benzene are even higher, increasing from $20 \mathrm{pptv}$ in the stratosphere to approx. $130 \mathrm{pptv}$. The concentrations during the event were higher than background concentrations in the upper troposphere, indicating that polluted boundary layer air was directly mixed into the lowermost stratosphere.
\end{abstract}

\section{Introduction}

Tropospheric ozone plays a key role for the oxidizing power of the atmosphere, owing to its role as $\mathrm{OH}$ precursor. Sources of tropospheric $\mathrm{O}_{3}$ are: downward transport from the stratosphere (e.g. Holton et al., 1995, and references therein); and in-situ photochemical production involving volatile organic compounds, carbon monoxide and nitrogen oxide (e.g. Crutzen, 1995). The majority of ozone precursors are emitted close to the earth's surface. Large scale mixing of pollution throughout the troposphere is accomplished by frontal activity (e.g. Bethan et al., 1998; Fischer et al., 2002) and deep convection, a particularly efficient process for fast

Correspondence to: H. Fischer (hofi@mpch-mainz.mpg.de) transport of boundary layer air into the upper troposphere (Dickerson et al., 1987; Pickering et al., 1988; Hauf et al., 1995; Ström et al., 1999). Tropospheric air enters the stratosphere predominantely in the tropics as part of the large scale Brewer-Dobson-circulation (Holton et al., 1995), with a small contribution from deep convection penetrating the tropical tropopause (Danielsen, 1982, 1993). In the extratropics additional troposphere to stratosphere transport can be related to either diabatic processes, e.g. via mid- or high latitude convection, or adiabatic transport along isentropes that cross the tropopause, e.g. in the vicinity of tropopause breaks associated with the subtropical and the polar front jet streams. First indications that deep convection associated with midlatitudinal thunderstorms can also contribute to troposphere-to-stratosphere transport were obtained from airborne infrared radiometric interference measurements in the early 1970s (Kuhn et al., 1971; Kuhn and Stearns, 1973), which demonstrated that convective systems can introduce significant amounts of water vapour into the lower stratosphere (Reiter, 1975). Further evidence for troposphere-tostratosphere transport in midlatitude convective complexes was obtained from airborne in-situ measurements of $\mathrm{O}_{3}$, NOy, CO and $\mathrm{H}_{2} \mathrm{O}$ by Poulida et al. (1996). Convective injection of biomass burning debris from large scale boreal fires into the lowermost stratosphere was demonstrated by Waibel et al. (1999), Fromm et al. (2000) and Siebert et al. (2000). Although Hauf et al. (1995) and Ström et al. (1999) demonstrated that deep convection can pump boundary layer air without significant dilution to the tropopause region, experimental verification that this air directly influences the lower stratosphere is still limited. Here we report airborne in-situ observations made during the Mediterranean INtensive Oxidant Study (MINOS) in August 2001 of crosstropopause transport of boundary layer air into the lowermost stratosphere at midlatitudes, well above the local tropopause. 
a)

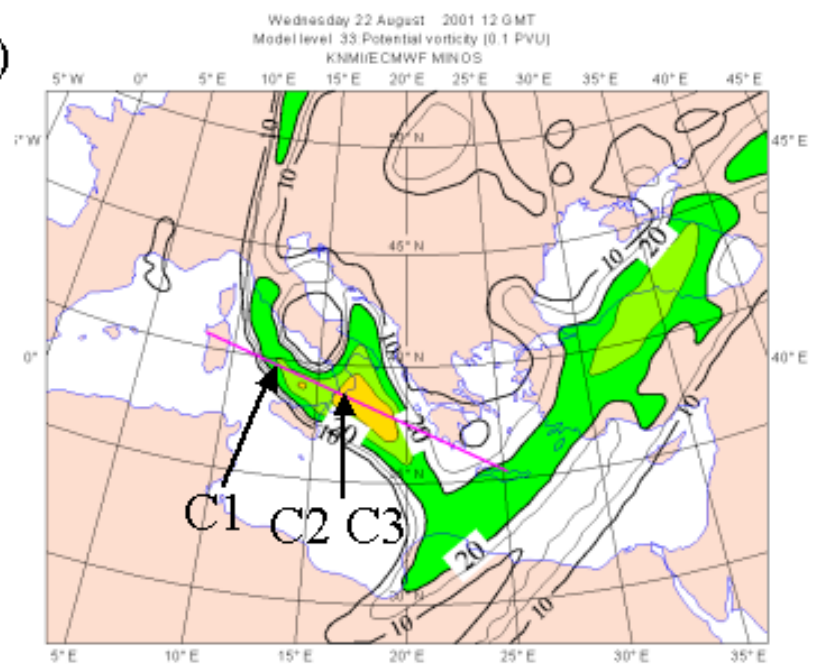

b)

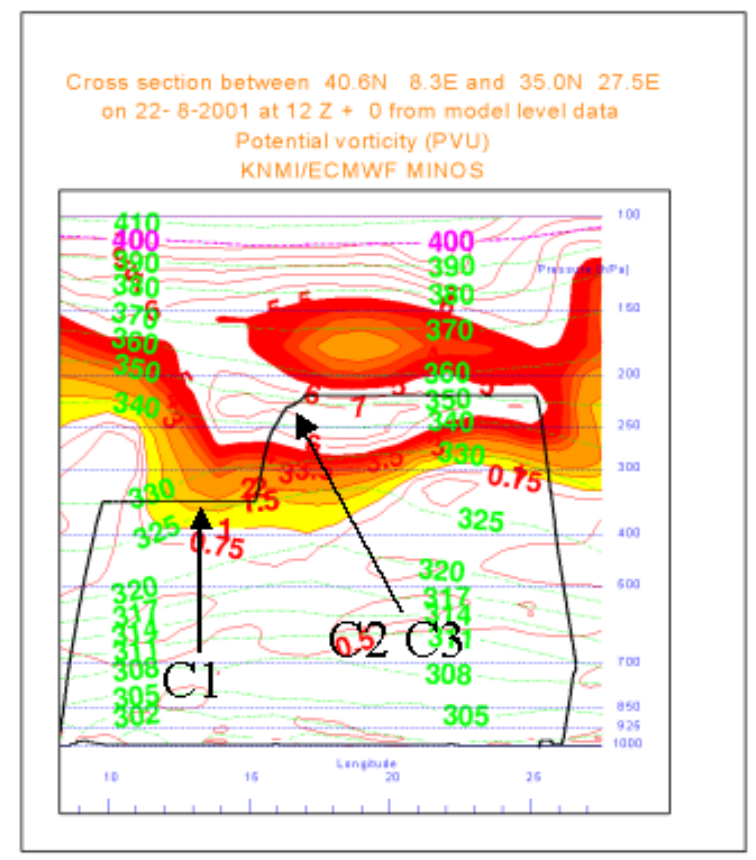

Fig. 1. (a) Potential vorticity in units of $0.1 \mathrm{PVU}\left(1 \mathrm{PVU}\right.$ is $10^{-6} \mathrm{~K}$ $\mathrm{m}^{2} \mathrm{~s}^{-1} \mathrm{~kg}^{-1}$ ) at the $300 \mathrm{hPa}$ level on 22 August 2001, 12:00 GMT. Stratospheric air is characterized by PV levels in excess of 20 (2 $\mathrm{PVU}$ ). Superimposed on the figure is the approximate aircraft trajectory (pink line). (b) Potential vorticity cross section along the pink line in (a). The tropopause region ( $1-3 \mathrm{PVU})$ is demarked by colouring. The flight trajectory is shown in black. $\mathrm{C} 1$ to $\mathrm{C} 3$ mark the positions of observed convective injection of tropospheric air into the lower stratosphere.

\section{Meteorological situation}

On 22 August 2001 an upper level trough developed over southern Italy associated with a surface low centred east of Rome, causing a low tropopause over the Tyrrhenian sea and the southern tip of Italy (Fig. 1). Cloud cover images in
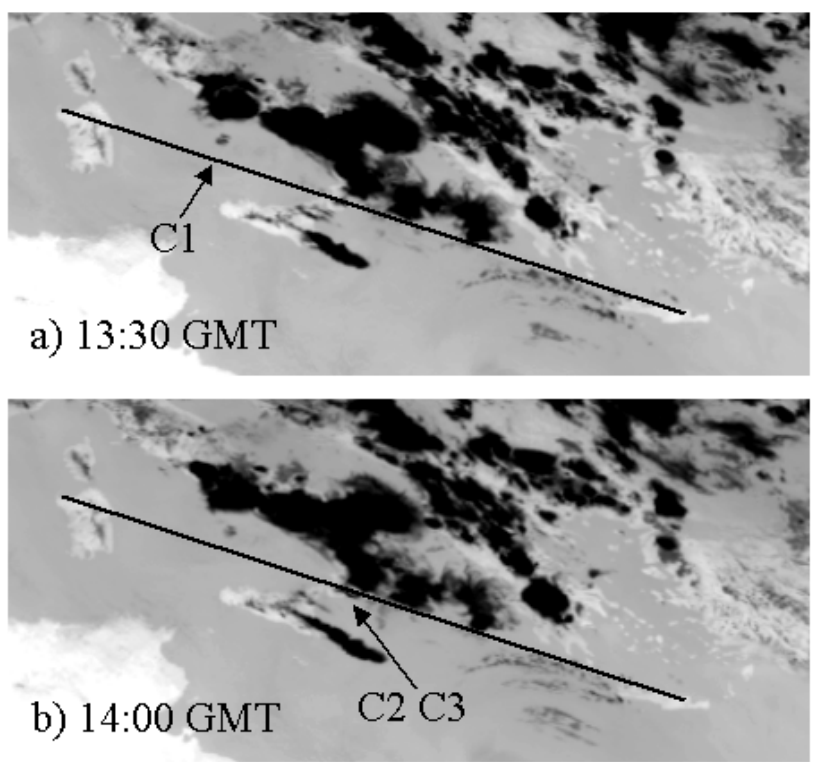

Fig. 2. Meteosat IR images obtained at 13:30 and 14:00 GMT. The lines indicate the approximate flight trajectory. Trace gas enhancements at the tropopause due to convection were observed between 13:15 and 13:21 GMT in the outflow of the clouds west of Italy (C1) and between 13:45 and 13:50 over the southern tip of Italy (C2 and C3).

the infra-red spectral range taken by Meteosat satellites at 13:30 GMT and 14:00 GMT on 22 August 2001 are shown in Figs. 2a and 2b, respectively. Both figures indicate the development of strong convection in this area during noon. The approximate flight track of the German research aircraft Falcon on its way from Sardinia to Crete is superimposed on the pictures. Take-off from Alghero airport (Sardinia, $40.5^{\circ} \mathrm{N}$, $8.5^{\circ} \mathrm{E}$ ) took place on 12:46 GMT, landing at Heraklion airport (Crete, $35.3^{\circ} \mathrm{N}, 25.1^{\circ} \mathrm{E}$ ) on 15:23 GMT. The aircraft passed the area of strong convection above the Thyrrenian and Ionian seas between 13:15 GMT and 13:55 GMT.

\section{Measurements}

Figure 3 shows the time series of trace gas concentrations from a merged data set with a resolution of $15 \mathrm{~s}$ obtained during the first hour of the flight from Sardinia to Crete between 12:53 GMT and 14:00 GMT extending from Alghero to the east coast of the Italian peninsula at $40.5^{\circ} \mathrm{N}, 17.2^{\circ} \mathrm{E}$, while Fig. 4 shows altitude profiles of these tracers and potential temperature. $\mathrm{CH}_{4}$ and $\mathrm{CO}$ were measured by infrared absorption spectroscopy using the Max Planck Institute for Chemistry tuneable diode laser spectrometer TRISTAR (Wienhold et al., 1999) with a total uncertainty of $10 \%$ and $12 \%$, respectively. The DLR provided $\mathrm{O}_{3}$ measurement based on fast response UV absorption (total uncertainty 5\%), NO measurements by chemoluminescence (total uncertainty 


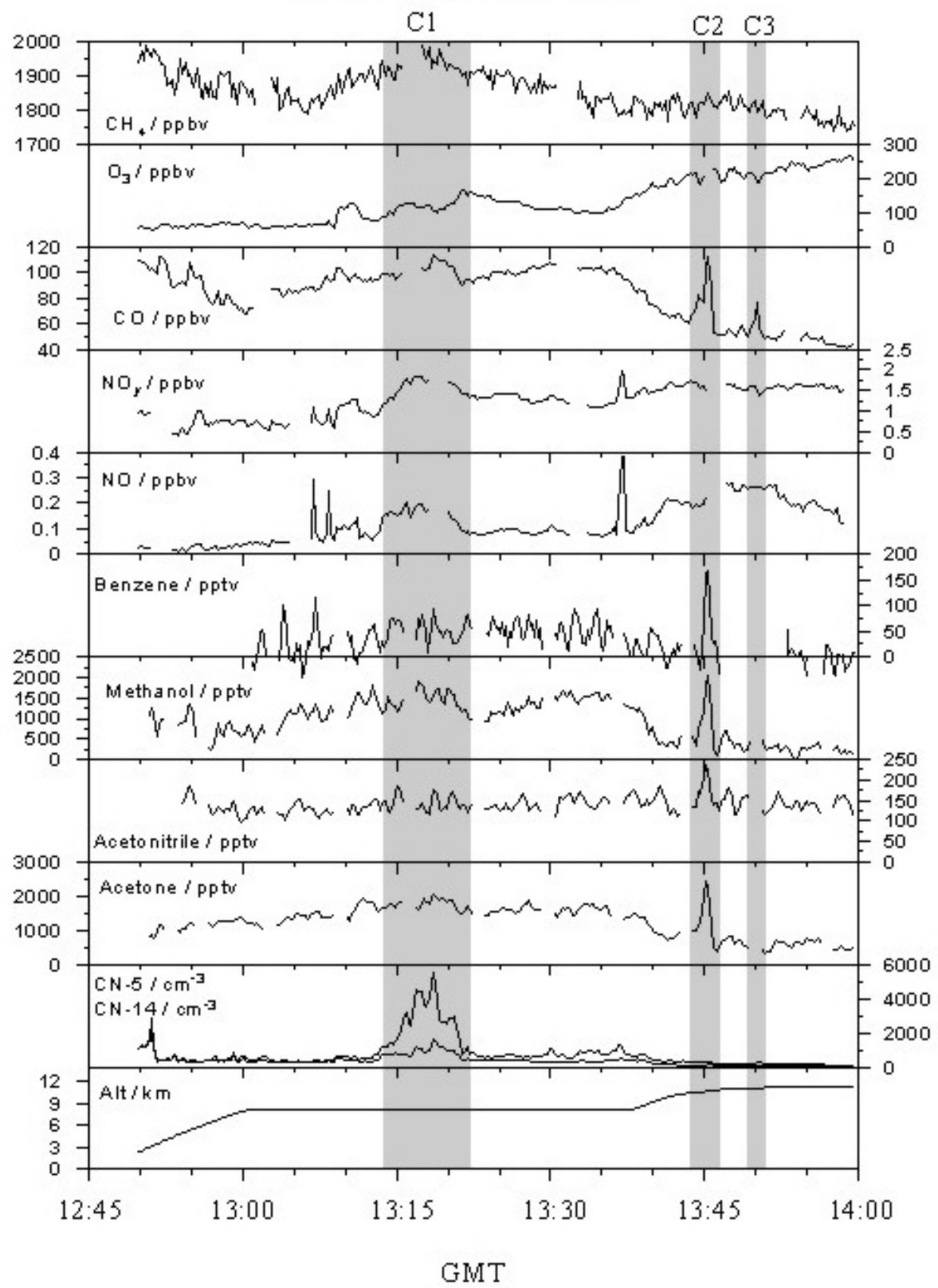

Fig. 3. Time series of trace gases measured during the first half of the MINOS measurement flight on 22 August 2001. Flight segments influenced by convection are highlighted in grey.

5\%), and gas phase NOy measurements (total uncertainty $15 \%$ ) via conversion of its single components to $\mathrm{NO}$ within a heated gold tube in the presence of $\mathrm{CO}$ as reducing agent (Ziereis et al., 2000). Methanol, acetonitrile, benzene, and acetone were measured with proton-transfer-reaction mass spectrometry (PTR-MS) (Lindinger et al., 1998) using two instruments, operated by the University of Utrecht and the Max Planck Institute for Chemistry. The instruments showed good agreement (de Gouw et al., 2002). In the following only data from the Utrecht PTR-MS are used because of the higher temporal resolution and the higher data coverage of this instrument. The total uncertainty of the PTR-MS measurements is of the order of $35 \%$. The particle number concentration was measured by two condensation particle counters with $50 \%$ counting efficiency at particle diameters of $5 \mathrm{~nm}(\mathrm{CN}-5)$ and $14 \mathrm{~nm}(\mathrm{CN}-14)$, respectively, operated by the DLR. The difference between $\mathrm{CN}-5$ and $\mathrm{CN}-14$ represents the nucleation mode or ultrafine particle number (UCN) concentration, with a diameter between 5 and $14 \mathrm{~nm}$. 
MINOS-Flight-14 220801c

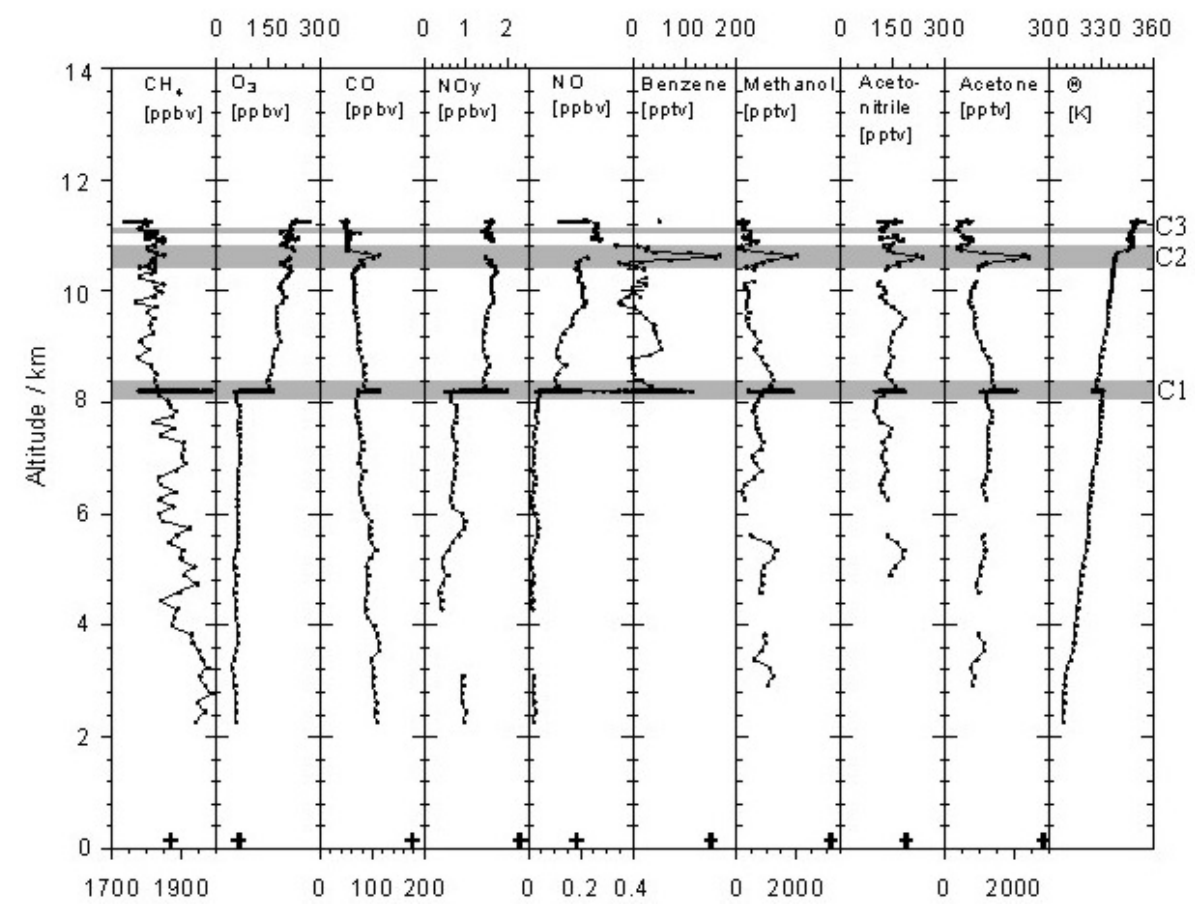

Fig. 4. Vertical profiles of measured trace gases and potential temperature during the first half of the MINOS flight on 22 August 2001 . The crosses at altitudes $<500 \mathrm{~m}$ denote boundary layer measurements performed over the Iovian sea, east of Italy on 19 July 2001.

Previous studies have used a large variety of chemical and physical tracers from in-situ measurements to infer the effect of convection on the chemical composition. Most techniques rely on detection of trace gas enhancements of species with higher concentrations in the boundary layer than in the free troposphere, e.g. CO, NOy, or NMHC (e.g. Dickerson et al., 1987; Poulida et al., 1996). Since outflow of larger convective clouds has recently been suggested as a source for new particles, UCN measurements have been widely used to detect convective outflow (de Reus et al., 2001; Clarke et al., 1999; Wang et al., 2000). Three events during which the trace gas signatures indicate transport of boundary layer air into or above the tropopause region are marked in grey in Figs. 3 and 4. The first event, labelled C1, was observed between 13:15 and 13:21 GMT around $39.7^{\circ} \mathrm{N}, 12.5^{\circ} \mathrm{E}$ (north of Sicily, approximately halfway between Sardinia and Italy) at $8.2 \mathrm{~km}$ altitude (Fig. 2a). The event is characterized by simultaneous enhancements in $\mathrm{CH}_{4}, \mathrm{CO}, \mathrm{NO}, \mathrm{NOy}$ and $\mathrm{UCN}$. Ozone levels in excess of $100 \mathrm{ppbv}$ and PV values of the order of 2 PVU (Fig. 1b) indicate the close proximity of the tropopause. As a consequence of the constant level flight this event can not be unambiguously identified in the profiles shown in Fig. 4. Shortly before this event (after 13:10 GMT) strong spikes in both $\mathrm{NO}$ and NOy, that were not associated with simultaneous enhancements in $\mathrm{CO}$, were observed. These enhancements are therefore not ascribed to deep con- vective pollution transport from the boundary layer. They are more likely associated with NO production by lightning, as they are too wide to be aircraft exhaust plumes. The same argument applies to a second NO/NOy peak around 13:36 GMT. Backward trajectories for event $\mathrm{C} 1$ indicate that the airmass origin 5 days prior to the measurements is in the upper troposphere off the east coast of the North American continent (note that trajectories before and after $\mathrm{C} 1$ show a similar behaviour with respect to the airmass origin). Figure 5a shows the trajectories during their final approach over Europe, indicating that the trajectories passed over the strong convection over the Italian mainland shortly before encountering the aircraft (compare to Fig. 2a).

Approaching the Italian west coast the aircraft was forced to climb to a higher flight level to stay clear of a large cumulonimbus cloud. Between 13:44 and 13:46 GMT the on-board operators reported close proximity to clouds and strong turbulence during passage over the southern tip of Italy $\left(39^{\circ} \mathrm{N}, 16.1^{\circ} \mathrm{E}\right)$ at an altitude of $10.3 \mathrm{~km}$. During this event, labelled C2 in Figs. 2b, 3, 4 and 5b, CO, methanol, acetonitrile, benzene, and acetone show strong and sharp increases exceeding the stratospheric background by up to a factor of two. The strongest enhancement is found for benzene, whose mixing ratio increased by approx. a factor of 5 relative to the stratospheric background, which is close to the detection limit of the instrument (20-50 pptv). Unfortunately 

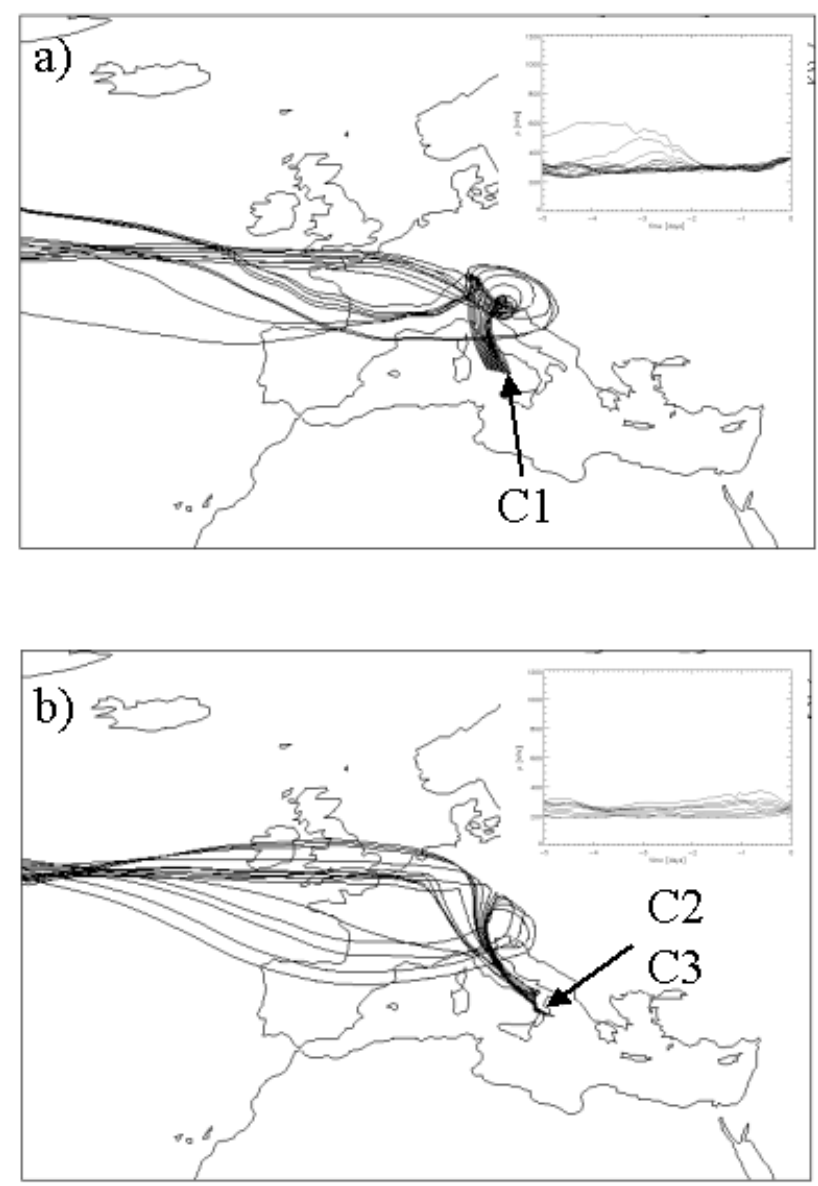

Fig. 5. Backward trajectories and their respective altitude variation for the period of event C1 (a) and C2 and C3 (b), respectively. Trajectories for $\mathrm{C} 1$ were calculated along the flight path at an interval of 1min between 13:10 and 13:25 GMT on 22 August 2001, while trajectories for $\mathrm{C} 2$ and $\mathrm{C} 3$ were calculated between 13:40 and 13:55 GMT.

the NO and NOy instrumentation provided no data during this period due to an on-board calibration. For the same reason, no $\mathrm{O}_{3}$ data are available between 13:45 and 13:46 GMT, right at the time of maximum enhancements in the tropospheric tracers.

The concentrations of acetone, methanol, benzene, and acetonitrile are in fact substantially higher than free tropospheric values during this particular flight (Fig. 4). They are, however, comparable to data obtained on 19 August 2001 during a flight west of Italy in the boundary layer over the Ionian sea at $36^{\circ} \mathrm{N}, 18^{\circ} \mathrm{E}, 116 \mathrm{~m}$ above sea level. This flight was designed to characterize west European outflow. Streamlines and backward trajectory calculations indicate that these airmasses were advected to the Ionian sea from southern Italy. The convective event $\mathrm{C} 2$, and the subsequent event C3 ( 13:50 GMT, $38.8^{\circ} \mathrm{N}, 16.8^{\circ} \mathrm{E}, 11 \mathrm{~km}$ altitude), were observed in the stratosphere, as indicated by $\mathrm{O}_{3}$ concentrations in excess of $200 \mathrm{ppv}$ and PV values of the order of 7
PVU (Fig. 1b). Five day backward trajectories for C2 and C3 indicate that the airmasses were advected from the North Atlantic region in the lower stratosphere, passing over the convective region over Italy shortly before encountering the aircraft (Fig. 5b). Note that contrary to $\mathrm{C} 1$, neither $\mathrm{C} 2$ nor $\mathrm{C} 3$ are associated with significant new particle formation, i.e. an enhancement in ultrafine particles. This could indicate, that above the tropopause new particle formation is inhibited by lack of gaseous precursors, or that for the same reason the particles have not grown yet to measurable sizes.

Inspection of Figs. 2a and $b$ reveals that all three events were observed downwind (C1) or directly above (C2 and C3) areas with large convective cloud cover. The close proximity to clouds and the strong enhancements of boundary layer tracers indicate that convective injection of tropospheric air through the tropopause region has caused the events $\mathrm{C} 1$ to C3.

\section{Amount of tropospheric air injected into the strato- sphere}

The amount of tropospheric air mixed into the lowermost stratosphere during the convective events $\mathrm{C} 2$ and $\mathrm{C} 3$ can be estimated from the budget of the insoluble trace gases $\mathrm{CO}$, methanol, acetone, benzene, and acetonitrile. Table 1 lists average mixing ratios and $1 \sigma$-standard deviations of the mixing ratios of these species in the boundary layer (BL), the upper troposphere (UT), the lowermost stratosphere (LMS) and during the events $\mathrm{C} 2$ and $\mathrm{C} 3$. Concentrations in the boundary layer are deduced from measurements on 19 August 2001 in airmasses advected from southern Italy to the Ionian sea. The upper tropospheric background concentrations were determined from in-situ measurements on 22 August between 13:00 and 13:08 GMT (Fig. 3). Trace gas levels in the lowermost stratosphere, unperturbed by convective injection of tropospheric air, were determined by averaging data obtained $150 \mathrm{~s}$ before and after the events $\mathrm{C} 2$ and $\mathrm{C} 3$, respectively. The concentrations in the convective events $\mathrm{C} 2$ and $\mathrm{C} 3$ are calculated from data points exceeding the stratospheric background concentrations by $3 \sigma$.

The trace gas mixing ratios during the events $\mathrm{C} 2$ and $\mathrm{C} 3$ can be calculated according to

$\mathrm{X}^{\mathrm{Ci}}=(1-\mathrm{a}) \mathrm{X}^{\mathrm{LMS}}+\mathrm{a}\left(\mathrm{b} \mathrm{X}^{\mathrm{BL}}+(1-\mathrm{b}) \mathrm{X}^{\mathrm{UT}}\right)$

$\mathrm{i}=2,3$

where $\mathrm{X}$ is the mixing ratio of the species under investigation and superscripts denote the reservoir. The parameter a gives the amount of tropospheric air mixed into the lowermost stratosphere, which itself can be composed of boundary layer air and/or upper tropospheric air. The mixture between these reservoirs is described by the parameter $b$. Since we cannot determine $b$ independently, we further consider only the extreme cases were either purely boundary layer air 
Table 1. Mean concentrations of boundary layer (BL), upper troposheric (UT), lowermost stratospheric (LMS) and convectively mixed $(\mathrm{C} 1-\mathrm{C} 3)$ airmasses $(1 \sigma$-standard deviations are given in brackets). The percentages indicate the amount of boundary layer air or upper tropospheric air mixed into the lowermost stratosphere

\begin{tabular}{lccccc}
\hline & CO/ppbv & Methanol/pptv & Acetonitrile/pptv & Benzene/pptv & Acetone/pptv \\
\hline BL & $176(2)$ & $3157(199)$ & $189(13)$ & $150(30$ & $2845(91)$ \\
UT & $83(7)$ & $911(261)$ & $122(14)$ & $40(40)$ & $1304(141)$ \\
LMS & $58(7)$ & $384(159)$ & $135(21)$ & $20(20)$ & $708(140)$ \\
C2 & $91(15)$ & $1406(490)$ & $194(35)$ & $130(50)$ & $1803(603)$ \\
$\%$ BL air & 28 & 37 & $>100$ & 85 & 51 \\
BL & $176(2)$ & $3157(199)$ & $189(13)$ & $150(30)$ & $2845(91)$ \\
UT & $83(7)$ & $911(261)$ & $122(14)$ & $40(40)$ & $1304(141)$ \\
LMS & $51(3)$ & NA & NA & NA & NA \\
C3 & $70(8)$ & NA & NA & NA & NA \\
$\%$ BL air & 15 & NA & NA & NA & NA \\
$\%$ UT air & 59 & NA & NA & NA & NA \\
\hline
\end{tabular}

$(b=1)$ and purely upper tropospheric air $(b=0)$ are mixed into the lowermost stratosphere. For these cases the amount of tropospheric air (TR) mixed into the lowermost stratosphere was calculated from:

$\mathrm{TR}=\left(\mathrm{X}^{\mathrm{Ci}}-\mathrm{X}^{\mathrm{LMS}}\right) /\left(\mathrm{X}^{\mathrm{BL}, \mathrm{UT}}-\mathrm{X}^{\mathrm{LMS}}\right)$.

As already noted during the discussion of Fig. 3 concentrations of $\mathrm{CO}$, acetone, acetonitrile, benzene, and methanol observed in $\mathrm{C} 2$ exceeded upper tropospheric mixing ratios, so that local transport of upper tropospheric air into the lowermost stratosphere can be excluded for this event. Estimates according to Eq. (2) for $\mathrm{CO}$, methanol, and acetone indicate that between 28 and $51 \%$ boundary layer air has been mixed into the tropopause region during $\mathrm{C} 2$. Higher percentages are calculated for acetonitrile and benzene. Note that the average concentration of acetonitrile during $\mathrm{C} 2$ is even higher than in the boundary layer, indicating that the data obtained on 19 August might not be representative for the inflow region on 22 August, at least for acetonitrile. One explanation could be an underestimation of the acetonitrile concentration owing to up-take by the ocean in the airmasses during their $\sim 24 \mathrm{~h}$ transport from Italy over the Ionian sea (Williams et al., 2001). During C3 no PTR-MS data are available, therefore, estimates are restricted to $\mathrm{CO}$ only, indicating that either $15 \%$ boundary layer or 59\% upper tropospheric air are injected into the stratosphere during this event.

It should be noted that these estimates suffer from a number of shortcomings, since direct measurements in the inflow area on this particular day were not performed. Therefore, it is hard to say how representative the measurements on 19 August, obtained in the marine boundary layer $\sim 24 \mathrm{~h}$ downwind of the Italian mainland, are for the convective inflow region on August 22. This uncertainty might at least partly explain the strongly diverging budget calculations e.g. for acetonitrile and CO.
To investigate the ultimate fate of the air in events $\mathrm{C} 2$ and C3 clusters of 10-day forward-trajectories were calculated. These trajectories indicate that the air in this blob will briefly re-enter the troposphere (a minimum value of $1.5 \mathrm{PVU}$ is reached 48 hours after the measurements), before it finally returns to the stratosphere (PV > 4). Therefore, it is likely, that additional mixing of tropospheric and stratospheric air masses will take place within the next two days after the measurments.

\section{Conclusions}

Measurements during a strong convective event over southern Italy in August 2001 indicate that boundary layer air can be directly injected into the lowermost stratosphere. Ozone levels exceeding $200 \mathrm{ppv}$ suggest that convection significantly overshoots the local tropopause. Budget estimates suggest that lower stratospheric air can contain up to $50 \%$ boundary layer air in such convective events. Close to the tropopause the convective injection of boundary layer air is associated with new particle formation due to gas-to-particle conversion. Well above the tropopause convectively driven particle formation was not observed, which could indicate either inhibited particle formation or growth due to washout or freeze-out of gaseous precursors or that the particles are still too small to be detected by the instrument, which has a cut-off diameter of $4-5 \mathrm{~nm}$.

To our best knowledge, a similar in-situ observation of troposphere-stratosphere exchange associated with deep convection at midlatitudes that reaches into the lower stratosphere has been reported only once in the open literature (Poulida et al., 1996). The fact that deep exchange associated with convection has not been observed more often might indicate that these events are rather rare and contribute only little to troposphere-stratosphere-exchange in the extra-tropics. 
Additional measurements are needed to quantify the role of penetrating convection as compared to isentropic exchange associated with synoptic disturbances at the jet streams.

Acknowledgements. We gratefully acknowledge the excellent collaboration with the pilots and technicians of the DLR Falcon. Additionally, we like to thank M. Lawrence, Ph. Stier and M. Schulz for in-field chemical weather forecasts, which proved to be very helpful in day to day flight planning.

\section{References}

Bethan, S., Vaughan, G., Gerbig, C., Volz-Thomas, A., Richer, H., and Tiddeman, D. A.: Chemical airmass differences near fronts, J. Geophys. Res., 103, 13,413-13,434, 1998.

Clarke, A. D., Eisele, F., Kapustin, V. N., Moore, K., Tanner, D., Mauldin, L., Litchy, M., Lienert, B., Carroll, M. A., and Albercook, G.: Nucleation in the equatorial free troposphere: Favorable environments during PEM-Tropics, J. Geophys. Res., 104, 5735-5744, 1999.

Crutzen, P. J.: Ozone in the troposphere, in Composition, Chemistry, and Climate of the Atmosphere, edited by H. B. Singh, Van Norstrand Reinhold, New York, 349-393, 1995.

Danielsen, E. F.: A dehydration mechanism for the stratosphere, Geophys. Res. Lett., 9, 605-608, 1982.

Danielsen, E. F.: In situ evidence of rapid, vertical, irreversible transport of lower tropospheric air into the lower tropical stratosphere by convective cloud turrets and by large-scale upwelling in tropical cyclones, J. Geophys. Res., 98, 8665-8681, 1993.

de Gouw, J. A., Warneke, C., Holzinger, R., Klüpfel, T., and Williams, J.: Inter-comparison between airborne measurements of methanol, acetonitrile and acetone using two differently configured PTR-MS instruments, manuscript in preparation, 2002.

de Reus, M., Krejci, R., Williams, J., Fischer, H., Scheele, R., and Ström, J.: Vertical and horizontal distribution of the aerosol number concentration and size distribution over the northern Indian Ocean, J. Geophys. Res., 106, 28 629-28 641, 2001.

Dickerson, R. R., Huffman, G. J., Luke, W. T., Nunnermacker, L. J., Pickering, K. E., Leslie, A. C. D., Lindsey, C. G., Slinn, W. G. N., Kelly, T. J., Daum, P. H., Delany, A. C., Greenberg, J. P., Zimmerman, P. R., Boatman, J. F., Ray, J. D., and Stedman, D. H.: Thunderstorms: An important mechanism in the transport of air pollutions, Science, 235, 460-465, 1987.

Fischer, H., Brunner, D., Harris, G. W., Hoor, P., Lelieveld, J., McKenna, D. S., Rudolph, J., Scheeren, H. A., Siegmund, P., Wernli, H., Williams, J., and Wong, S.: Synoptic tracer gradients in the upper troposphere over central Canada during the STREAM 1998 summer campaign, J. Geophys. Res., 107, D8, 10.1029/2000JD000312, 2002.

Fromm, M., Alfred, J., Hoppel, K., Hornstein, J., Bevilacqua, R., Shettle, E., Servranckx, R., Li, Z., and Stocks, B.: Observations of boreal fire smoke in the stratosphere by POAM III, SAGE II, and lidar in 1998, Geophys. Res. Lett., 27, 1407-1410, 2000.

Hauf, T., Schulte, P., Alheit, R., and Schlager, H.: Rapid vertical transport by an isolated midlatitude thunderstorm, J. Geophys, Res., 100, 22 957-22 970, 1995.
Holton, J. R., Haynes, P. H., McIntyre, M. E., Douglass, A. R., Rood, R. B., and Pfister, L.: Stratosphere-troposphere exchange, Rev. of Geophys., 33, 403-439, 1995.

Kuhn, P. M., Lojko, M. S., and Petersen, E. V.: Water vapor: Stratospheric injection by thunderstorms, Science, 174, 1319-1321, 1971.

Kuhn, P. M., and Stearns, L. P.: Radiometric observations of atmospheric water vapor injection by thunderstorms, J. Atmos. Sci., 30, 507-509, 1973.

Lindinger, W., Hansel, A., and Jordan, A.: On-line monitoring of volatile organic compounds at pptv levels by means of ProtonTransfer-Reaction Mass Spectrometry (PTR-MS): Medical applicarions, food control and environmental research, Int. J. Mass Spectrom. Ion Processes, 173, 191-241, 1998.

Pickering, K. E., Dickerson, R. R., Huffman, G. J., Boatman, J. F., and Schandt, A.: Trace gas transport in the vicinity of frontal convective clouds, J. Geophys. Res., 93, 759-773, 1988.

Poulida, O., Dickerson, R. R., and Heymsfield, A.: Stratospheretroposphere exchange in a mid-latitude mesoscale convective complex: 1. Observation, J. Geophys. Res., 101, 6823-6836, 1996.

Reiter, E. R.: Stratosphere-troposphere exchange processes, Rev. Geophys. and Space Phys., 13, 459-474, 1975.

Siebert, J., Timmis, C., Vaughan, G., and Fricke, K. H.: A strange cloud in the Arctic summer stratosphere 1998 above Esrange (68N), Sweden, Ann. Geophysicae, 18, 505-509, 2000.

Ström, J., Fischer, H., Lelieveld, J., and Schröder, F.: In-situ measurements of aerosol microphysical properties and trace gases in two cumulonimbus anvils over western Europe, J. Geophys. Res., 104, 12 221-12 226, 1999.

Waibel, A. E., Fischer, H., Wienhold, F. G., Siegmund, P. C., Lee, B., Ström, J., Lelieveld, J., and Crutzen, P. J.: Highly elevated carbon monoxide concentrations in the upper troposphere and lowermost stratosphere at northern midlatitudes during the STREAM II summer campaign in 1994, Chemosphere: Global Change Science, 1, 233-248, 1999.

Wang, Y., Liu, S. C., Anderson, B. E., Kondo, Y., Gregory, G. L., Sachse, G. W., Vay, S. A., Blake, D. R., Singh, H. B., and Thompson, A. M.: Evidence of convection as a major source of condensation nuclei in the northern midlatitude upper troposphere, Geophys. Res. Lett., 27, 369-372, 2000.

Williams, J., Fischer, H., Harris, G. W., Crutzen, P., Hoor, P., Hansel, A., Holzinger, R., Warneke, C., Lindinger, W., Scheeren, B., and Lelieveld, J.: High resolution measurements of organic trace gases over the tropical forest and the use of the variability and lifetime relationship as a novel method to calculate $\mathrm{HO}$ concentrations, J. Geophys. Res., 105, 20 473-20 486, 2000.

Wienhold, F. G., Fischer, H., Hoor, P., Wagner, V., Königstedt, R., Harris, G. W., Anders, J., Grisar, R., Knothe, M., Riedel, W. J., Lübken, F.-J., and Schilling, T.: TRISTAR - a tracer in-situ TDLAS for atmospheric research, Appl. Phys. B, 67, 411-417, 1998.

Ziereis, H., Schlager, H., Schulte, P., van Velthoven, P. F. J., and Slemr, F.: Distributions of NO, NOx and NOy in the upper troposphere and lower stratosphere between $28^{\circ}$ and $61^{\circ} \mathrm{N}$ during POLINAT 2, J. Geophys. Res., 105, 3653-3664, 2000. 